\title{
Bliver Trump enden på den internationale klimaindsats?
}

\section{Af Johan Møller Nielsen}

Succesen på COP21 i Paris var en tiltrængt sejr for multilateralismen. Kun et år efter triumfen har Donald Trump sat sig i spidsen for et USA, som netop var begyndt at indtage en global lederrolle på klimadagsordenen. Betyder det, at enogtyve års forhandlinger har været forgæves? Og hvor efterlader det den internationale klimaindsats?

"We are going to cancel the Paris climate agreement." Så kontant var udmeldingen på et vælgermøde under præsident Trumps valgkampagne. Selvom hans position på området siden hen synes at være blevet mere moderat, har hans valgsejr givet anledning til bekymring om den globale kamp mod klimaforandringer, som ellers har momentum i disse år.

Lige så længe klimaforandringer har været et storpolitisk emne, har politikere sat deres lid til, at udfordringerne bedst tackles gennem multilaterale forhandlinger mellem alle verdens lande.

Forhandlingerne forudsætter en verdensorden, hvor staterne i det internationale system anerkender hinandens gensidige interesse $i$ at bremse den globale opvarmning. Derfor giver Trumps kontroversielle udmeldinger anledning til en diskussion om, hvorvidt den multilaterale proces skal overgå til historiebøgerne. Men der er grund til at slå koldt vand i blodet. For selvom den internationale klimaindsats i FN langt fra er fremtidssikret, er det en overdrivelse at frygte, at dens overlevelse først og fremmest afhænger af den nye amerikanske præsident.

\section{En global problemstilling}

Det, der særligt adskiller klimaforandringer fra mange andre typer forurening, er problemets globale natur.

Før det for alvor blev et populært politikområde i løbet af 1960'erne, blev miljøproblemer i høj grad betragtet som nationale anliggender. Rachel Carsons klassiker Silent Spring fra 1962 betragtes af mange som startskuddet på en folkelig miljøbevidsthed. I bogen berettede Carson, som var biolog, om konsekvenserne af den omfattende brug af sprøjtemidler i samtidens amerikanske landbrug. Bogen er fyldt med skræmmeeksempler på konsekvenserne af menneskelige forstyrrelser af økosystemer - men mestendels i en national eller regional kontekst.

Tredive år senere stod det imidlertid fuldstændig klart, at visse miljøproble- 
matikker måtte adresseres på internationalt plan. I slutningen af 1980'erne advarede klimaforskeren James Hansen den amerikanske kongres om stigende globale temperaturer og informerede dens medlemmer om, at opvarmningen med 99 pct. sikkerhed kunne tilskrives ophobningen af drivhusgasser i atmosfæren. Siden da har rapport efter rapport fremført den samme konklusion med fortsat tiltagende styrke.

Klimaforandringerne udgør et klassisk eksempel på et globalt problem, fordi den øgede drivhusgaseffekt har virkning over hele kloden og har implikationer for alle mennesker, hvad enten man har bidraget til problemet eller ej. Ingen aktører kan løse problemet alene, fordi den enkelte stats indsats forslår som én skrædder i helvede, hvis ikke andre stater følger trop. Derfor er det oplagt, at løsningen på det globale problem må være global handling.

Denne tankegang lå til grund for, at hele 172 regeringer vedtog FN's klimakonvention, eller United Nations Framework Convention on Climate Change (UNFCCC), ved en konference i Rio de Janeiro i 1992. Allerede på første side af den vedtagne aftale fremgår det, at "the global nature of climate change calls for the widest possible cooperation by all countries". Hermed lagde det internationale samfund kimen til, at globale klimaforandringer skulle forsøges løst gennem en multilateral proces i FN. Og det er den vej, verden den dag i dag følger.

\section{Trump og det internationale samfund}

Med Parisaftalen fra 2015 lykkedes det de Forenede Nationer at blive enige om en global klimaaftale. Mens aftalen hyldes for dens store omfang af inklusion det faktum, at alle lande bakker op om den - er dette også dens akilleshæl. Det er blevet gjort særdeles tydeligt med valget af Trump som USA's præsident.

Det er svært at blive klog på nøjagtigt, hvad den nye præsident mener om klimaforandringer, endsige hvad hans tilsigtede politik er på området. Man kan dog få et fingerpeg ved at betragte Trumps valg til at lede det føderale Environmental Protection Agency (EPA), den forhenværende republikanske justitsminister i Oklahoma, Scott Pruitt.

Ud over at forholde sig skeptisk til klimavidenskaben er Pruitt af den holdning, at den føderale regering blander sig for meget i delstatspolitik og amerikansk erhvervsliv, og på den baggrund har han ad flere omgange sagsøgt EPA. Da EPA ellers er den myndighed, der skal sikre implementeringen af Parisaftalen, er det rimeligt ikke ligefrem at forvente proaktiv klimapolitik fra Trumps regering, så længe Pruitt står i spidsen.

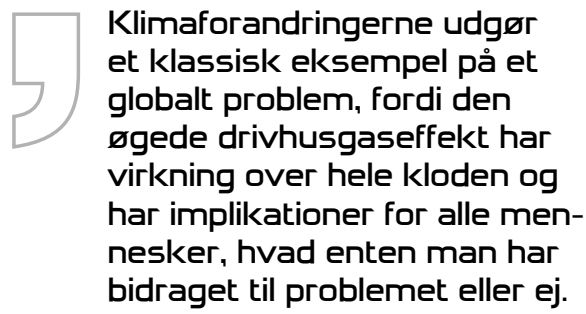

For så vidt angår de multilaterale klimaforhandlinger, har Trump grundlæggende tre muligheder, hvis han vil gøre alvor af sine valgløfter: Han kan trække USA ud af Parisaftalen; han kan melde USA ud af UNFCCC (og dermed Parisaftalen i samme omgang); eller han kan spare sig besværet og simpelthen undlade at efterleve USA's forpligtelser i aftalen.

Hvad end han ender med at gøre, kan det betragtes som en de facto udmeldelse af aftalen, og dermed bryder han med 
den regelbaserede verdensorden, som ligger til grund for forhandlingerne $\mathrm{i}$ UNFCCC.

I studier af international politik taler man somme tider om graden af 'internationalt samfund', hvormed man henviser til omfanget af fælles normer og gensidig forståelse mellem staterne i det internationale system.

Et sådant internationalt samfund er essentielt for, at internationale konventioner overhovedet kan eksistere; uden tillid til hinanden ville ingen stater have incitament til at efterleve deres aftaler. Men med udsigten til, at så stor en spiller som USA i bedste fald ignorerer Klimakonventionen - kun måneder efter at den historiske aftale fra Paris er trådt $\mathrm{i}$ kraft står det internationale samfund til at lide et nederlag.

Er det ensbetydende med, at Trump kan give dødsstødet til det multilaterale samarbejde, der i årtier har fundet sted på klimaområdet?

\section{Fra Kyoto til Paris}

Siden 1992 har UNFCCC været omdrejningspunktet for de internationale klimaforhandlinger. Fra konventionens ikrafttrædelse har parterne afholdt årlige topmøder i forsøget på at realisere den ambitiøse vision, man enedes om i Rio. Og som bekendt er det ikke altid gået lige nemt.

Det første forsøg på en implementering var Kyoto-protokollen, som blev vedtaget på parternes tredje møde, COP3, i 1997. I modsætning til Parisaftalen fra 2015 var kun udviklede lande bundet til at reducere deres drivhusgasudledninger under Kyoto-protokollen. Og af de lande, som var omfattet af protokollen, var det langt fra alle, der efterlevede den.

\section{Det er alment kendt, at Parisaftalen ikke er tilstræk- kelig til at leve op til målsæt- ningen om at begrænse den globale temperaturstigning til 'godt under' to grader, som det hedder i aftaleteksten.}

Eksempelvis havde Canada forpligtet sig til at reducere de nationale udledninger med seks pct. i 2012 sammenlignet med 1990. Da perioden kom til en ende, og det stod klart, at Canadas udledninger slet ikke var faldet, men i virkeligheden var steget med 30 pct., kunne verdenssamfundet imidlertid ikke gøre meget andet end at pege fingre.

Det udstiller den centrale svaghed ved UNFCCC, at der ikke er nogle konkrete sanktioner ved at løbe fra sine klimaløfter. Det er der fortsat ikke den dag i dag.

På trods heraf lykkedes det faktisk de udviklede lande - samlet set - at efterleve målsætningen om fem pct. reduktion i 2012 sammenlignet med 1990. I samme periode blev disse beskedne reduktioner dog mere end opvejet af udledningerne fra de store vækstøkonomier og USA, som ikke tog del i protokollen. Da Kyoto-perioden nærmede sig sin afslutning, stod det derfor klart, at en mere omfattende, global aftale måtte afløse Kyoto-protokollen.

Efter et fejlslagent forsøg ved COP15 i København lykkedes det endelig, efter enogtyve års forhandlinger, at ramme plet i Le Bourget i det nordlige Paris.

Det er alment kendt, at Parisaftalen ikke er tilstrækkelig til at leve op til målsætningen om at begrænse den globale temperaturstigning til 'godt under' to grader, som det hedder i aftaleteksten. Men aftalen er alligevel historisk, fordi det lykkedes at få samtlige parter til 
UNFCCC med om bord. Multilateralismen sejrede. Endelig.

\section{Parisaftalens skrøbelige legitimitet}

Som alle andre internationale organisationer har UNFCCC brug for en kombination af legitimitet og effektivitet til at sikre opbakning nu og i fremtiden. Opbakningen til de multilaterale klimaforhandlinger afhænger således på den ene side af den høje grad af inklusion og det konsensusbaserede system, og på den anden side af de konkrete resultater, som aftalen giver anledning til i den virkelige verden.

Beslutninger i FN, herunder i UNFCCC, er generelt kendetegnet ved en høj grad af legitimitet, fordi de træffes ved konsensus. Det tvinger ethvert givent formandskab til at formulere kompromiser, som alle knap 200 parter kan enes om. Det er en omstændelig og uhyre kompleks proces, hvad den enogtyve år lange vej til verdens første globale klimaaftale vidner om.

Netop af den grund nyder den p.t. gældende aftale så meget desto mere legitimitet. Siden aftalens vedtagelse i Paris er den blevet ratificeret i de enkelte nationalstater med så stor hast, at den nåede at træde i kraft, inden parterne igen mødtes til COP22 i Marokko - mindre end et år efter aftaleteksten blev vedtaget. Til sammenligning tog samme proces mere end syv år for Kyoto-protokollen. Under COP22 var der ydermere et stort fokus på, at alle parter eksplicit genbekræftede deres opbakning til aftalen. I den forstand er Parisaftalens legitimitet $\mathrm{i}$ absolut top.

Hvad så, hvis Trump trækker USA ud af forhandlingerne? Af mindst to årsager vil det tære på UNFCCC's legitimitet. For det første har FN’s klimaforhandlin- ger altid centreret sig om det princip, at de, der bærer det største ansvar for krisen, også skal trække det tungeste læs. Princippet er kendt som 'common but differentiated responsibilities' og var årsagen til, at kun udviklede lande havde juridiske forpligtelser under Kyoto-protokollen. Selvom der med Parisaftalen er sket en mindre opblødning af dette dogme, tilsiger enhver sans for ret og rimelighed, at USA som verdenshistoriens største udleder af drivhusgasser naturligvis skal være en central del af løsningen på klimaproblematikken. Og det er tilsyneladende ikke ligefrem tilfældet under Trumps administration.

For det andet udstiller Trumps modvillighed den svaghed ved Parisaftalen, at ingen stater troværdigt kan garantere for at opfylde deres reduktionsmålsætninger. Nøjagtig som da hele verden pegede fingre af Canada i forbindelse med Kyoto-protokollen, er der intet konkret til hinder for, at Trump kan lukke øjnene for de amerikanske forpligtelser under Parisaftalen.

Spørgsmålet er, om aftalen da overhovedet kan bruges til noget som helst? Hvis staterne i det internationale system ikke gensidigt stoler på hinandens intentioner, har den multilaterale proces intet fundament at stå på.

Den i øjeblikket store opbakning, der stammer fra det internationale samfunds brede tilslutning til fælles mål og principper, kommer derfor alt andet lige til at lide et tab under Trump. Men det betyder ikke nødvendigvis enden på UNFCCC, som før har overlevet uden USA om bord. Opbakningen til den multilaterale proces kommer nemlig i høj grad til at afhænge af, hvorvidt Parisaftalen viser sig effektiv til det, den er sat i verden for: at bekæmpe klimaforandringer. 


\section{En aftale uden USA?}

Det er uhyre svært, for ikke at sige umuligt, at isolere effekten af Trump på sandsynligheden for at begrænse den global opvarmning til under to grader over førindustrielt niveau. Forskere har svært nok ved at tackle dette spørgsmål uden Trump i ligningen.

FN's miljøprogram UNEP estimerede sidste år, at selv hvis alle verdens lande lever op til deres nuværende forpligtelser under Parisaftalen, kan vi forvente minimum tre graders opvarmning til følge.

Det er ingen overraskelse. Faktisk vidste verdens ledere i Paris udmærket godt, at der skulle mere til. Af den grund vedtog man den såkaldte ambitionsmekanisme, som skal sikre, at parterne til aftalen løbende opjusterer deres reduktionsbidrag. Det er derfor ikke utænkeligt, at man i de kommende år presser citronen så meget, at tograders-målsætningen igen kommer inden for rækkevidde. Ikke utænkeligt, men dog ret usandsynligt. Spørgsmålet er, hvor meget mindre sandsynligt det bliver af, at Trump er ved roret.

Det Internationale Energiagentur, IEA, har fremskrevet et scenarie, hvor USA som den eneste part til Parisaftalen undlader at efterleve sine forpligtelser. I det tilfælde estimeres det, at ti pct. af de forventede udledningsreduktioner i 2040 vil gå tabt sammenlignet med et scenarie, hvor også USA overholder sin del af aftalen.

Ti pct. af verdens samlede udledninger over en tyveårig periode - det er en ganske substantiel mængde drivhusgasser. Men kan man antage, at udviklingen i USA's udledningsniveau fortsætter som hidtil, blot fordi Trump sidder i Det Hvide Hus?
Ikke nødvendigvis. IEA kunne i deres seneste årlige energirapport berette, at væksten i globale drivhusgasudledninger fra energisektoren er gået i stå. En fortsat større del af verdens årlige energiinvesteringer går til vedvarende energi, hvilket resulterer i, at der globalt set opsættes mere ny energikapacitet baseret på vedvarende energikilder end på kul, olie og gas. Og subsidier til fossile brændsler gik fra næsten 500 mia. dollars i 2014 til 'kun' 325 mia. dollars i 2015.

Oven i disse trends kommer, at de globale drivhusgasudledninger har været konstante de sidste tre år, hvorfor forskere nu diskuterer, om $\mathrm{CO}_{2}$-udledningerne fra fossile brændsler mon topper netop nu. Globalt set er omstillingen til lavemission altså i gang, hvad enten Trump vil det eller ej.

Også inden for nationens grænser er Trumps handlerum begrænset, blandt andet fordi de amerikanske delstater har autonomien til at iværksætte deres egne klimapolitikker uafhængigt af den føderale regering.

For eksempel bliver Barack Obamas Clean Power Plan (CPP), der var tænkt som hjørnestenen i USA's implementering af Parisaftalen, formentlig skrottet på Trumps vagt. Af mange anses dette for konkret at være dødsstødet til USA's klimaindsats. Ikke desto mindre har Californien - den mest folkerige delstat $\mathrm{i}$ landet og verdens sjette største økonomi - gjort det til en lokal målsætning at leve op til sine forpligtelser under CPP, uagtet om planen tages af bordet på føderalt niveau. Californien er således godt på vej mod et udledningsniveau svarende til 1990, og staten har - ligesom 28 andre delstater - valgt at indføre sine egne standarder for vedvarende energi. 
Samlet set tegner der sig et billede af, at visse bevægelser på såvel internationalt som subnationalt niveau stryger Trumps forventede klimapolitik mod hårene.

Det betyder ikke, at implementeringen af Parisaftalen sker af sig selv. Langt fra. Men det vidner om, at den amerikanske præsident trods alt kun er en lille brik i det enorme puslespil, der må gå op, hvis den globale opvarmning skal begrænses til under to grader.

\section{Fremtidens klimaindsats}

Det er næppe præsident Trump, der kommer til at afgøre, om der også i fremtiden vil være opbakning til UNFCCC som det faciliterende organ for den globale klimaindsats.

Ganske vist kan han de facto melde USA ud af Parisaftalen fra den ene dag til den anden - hvilket vil være et stort tilbageslag for den internationale indsats' legitimitet - men ultimativt afhænger UNFCCC's berettigelse og dermed overlevelse af, om der præsteres på klimadagsordenen over de kommende år.

Hvorvidt Parisaftalen implementeres succesfuldt afhænger af en lang ræk- ke faktorer, hvoraf Trump kun har indflydelse på meget få. Der er derfor grund til at nedtone frygten for, at Trumps embedsperiode skulle betyde de internationale klimaforhandlingers endeligt.

2023 bliver et vigtigt år for de multilaterale forhandlinger. Her mødes parterne til Parisaftalen på COP29 for formelt at gøre status over den globale klimaindsats, både i relation til de nuværende nationale reduktionsforpligtelser og sandsynligheden for at opfylde tograders-målsætningen. Her vil det altså vise sig, om USA - og alle andre parter - er på vej til at overholde løfterne fra Paris. Og det er formentlig også her, at vi får at se, om Trumps regeringsperiode ender med at sætte et markant aftryk på de amerikanske drivhusgasudledninger.

Opbakningen til UNFCCC står og falder med, om vi om fem til ti år begynder at kunne måle markante effekter af Parisaftalen på globalt plan. Og i sidste ende er det trods alt begrænset, hvor stor en indflydelse Donald Trump har på dét spørgsmål - ene mand. 